\title{
Ammonium regeneration in eutrophicated coastal waters of Sweden
}

\author{
Johanne-Sophie Selmer
}

\author{
Department of Marine Microbiology, University of Göteborg, Carl Skottsbergs Gata 22, S-413 19 Göteborg, Sweden
}

\begin{abstract}
Rates of ammonium regeneration were measured in the Kattegat and Laholm Bay, a shallow, eutrophicated embayment in the southeastern Kattegat. Over the year, average rates in the central outer part of Laholm Bay were $51 \mathrm{nmol} \mathrm{l}^{-1} \mathrm{~h}^{-1}$ and near the outlet of the River Nissan $49 \mathrm{nmol}$ $\mathrm{l}^{-1} \mathrm{~h}^{-1}$. Elevated rates were observed during the peak of the spring bloom, and rates increased with depth throughout spring (contrary to autumn, when rates decreased with depth). Diel variations were more pronounced in March (with rates during night and early morning 7 times higher than those in the evening) than in September when variations were within the error of the method. Rates measured during autumn in the central outer part were 2.5 times higher than in spring. Correcting these for the observed diel variations resulted in 1.5 times higher rate of ammonium regeneration during autumn. In a transect extending outwards from the River Nissan, a positive correlation between the recycling factor (r) and the ammonium regeneration rate was found, even if the ammonium regeneration contributed only to part of the ammonium uptake (due to allochthonous ammonium input from the river). Ammonium regeneration rates $(R)$ were generally found to exceed those of ammonium uptake $(U)$. resulting in ratios of $U: R$ being $<1$, and should be considered as potential rates.
\end{abstract}

\section{INTRODUCTION}

The importance of nitrogen in the marine environment lies in its role as the limiting nutrient in phytoplankton growth. This was observed in coastal waters by Ryther \& Dunstan (1971) who ascribed this situation to the low regeneration rate of nitrogen as compared to phosphorus. More recently, Smith et al. (1986) showed for oceanic waters that the nitrogen limitation is a result of slower biochemical turnover of dissolved organic nitrogen than of dissolved organic phosphorus. Dugdale \& Goering (1967) introduced the concept of new and regenerated production where new production is based on uptake of allochthonously supplied nutrients (mostly nitrate transported to the photic zone by upwelling and land runoff) and regenerated production is based on autochthonously supplied nutrients (mostly ammonium, and also urea, which are recycled within the photic zone). Since ammonium is the preferred nitrogen source of phytoplankton (McCarthy 1980) and regenerated production can amount to as much as $94 \%$ in oceanic waters (Eppley \& Peterson 1979), the process of ammonium regeneration is of the greatest importance in sustaining phytoplankton production. Eppley \& Peterson (1979) restricted the application of the concept of new and regenerated production to waters where there will be no input of reduced nutrients from the sediment or land runoff. This is especially relevant in coastal waters where there are high inputs of ammonium and urea from sewage plant outlets and agricultural runoff (Wassmann 1986).

Increased attention has been paid to the quantification of ammonium regeneration, as this is the main supply of regenerated nitrogen. In theory, nutrient regeneration rates are expected to equal nutrient uptake rates in a steady-state ecosystem (Goldman \& Glibert 1983). This has been observed in both oceanic and coastal waters, but in most cases regeneration rates have been reported to exceed uptake rates. This excess of regeneration over uptake might indicate an overestimation of the rates of ammonium regeneration, as has been proposed by several authors (e.g. Glibert 1982, Cochlan et al. 1986, Kokkinakis \& Wheeler 1987). Glibert (1982) concluded that the high rates of ammonium regeneration might be the result of bottle confinement and that high remineralization rates measured from a bottle experiment do not necessarily indicate that such rates are sustained throughout the water column, but rather that the potential exists for this process to be important'. Seasonal variations in the ammonium regeneration rate have been interpreted as changes in metabolic activities due to variations in 
water temperature (Glibert 1982). Ammonium regeneration rates are reported to be enhanced during the night (Caperon et al. 1979, Glibert 1982), a phenomenon often ascribed to vertical migration of zooplankton.

An increased load of nitrogen from external sources will enhance both the fraction of new production and the amount of total production (Laws 1983). Elevated productivity caused by eutrophication has been observed in a number of coastal environments around the world. In Sweden observations of reduced benthic fauna and demersal fish catches concomitant with low oxygen levels in Laholm Bay (a shallow embayment in the southeastern Kattegat; Fig. 1), was reported by Rosenberg (1985). Laholm Bay receives an external nitrogen input of 4800 tonne $\mathrm{yr}^{-1}$, mainly from the land (Rydberg 1986). This external nutrient input has caused a $25 \%$ increase in primary production during the last decade (Edler 1986).

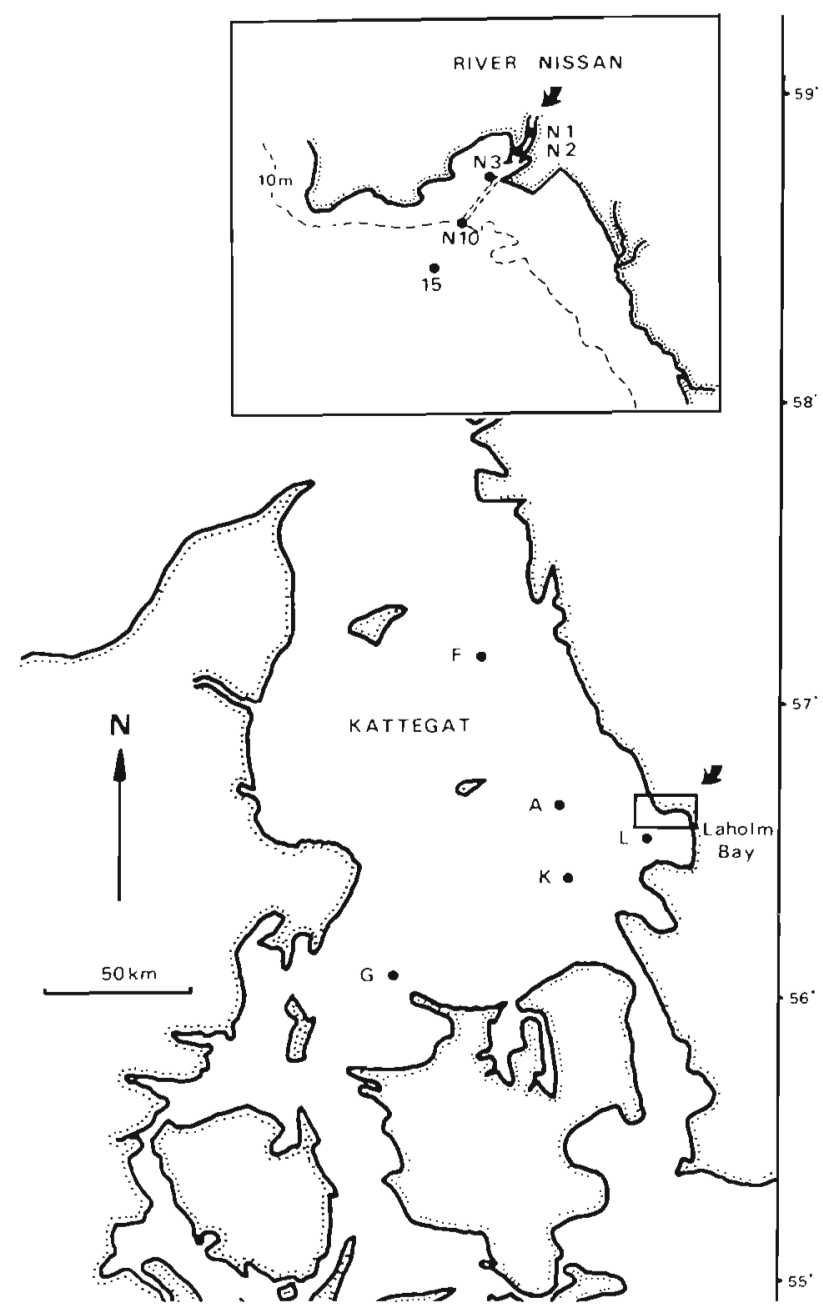

Fig. 1. The Kattegat with enlargement of the outlet of the river Nissan and transect stations. Stations: $A$, Anholt $E_{;} F$, Fladen; G. Gniben; K, KX1; L, central outer part of the Laholm Bay
In the present paper, ammonium regeneration rates from the Kattegat and Laholm Bay are presented and discussed in relation to nutrient uptake measurements in the same area (Sahlsten et al. 1988, Pettersson et al. unpubl.). Three main questions have been addressed: (1) Is there a correlation between the ammonium regeneration rate and the fraction of regenerated production in waters where there is an external input of ammonium? (2) Is there a diel variation in the ammonium regeneration rate? (3) Is there a seasonal variation in the ammonium regeneration rate?

This study forms part of an interdisciplinary research program aiming at surveillance of the eutrophication of Swedish coastal waters, and directed towards understanding the dynamics of this process.

\section{MATERIALS AND METHODS}

Study site. Laholm Bay is characterised by strong vertical stratification, with low salinity in the surface water and high salinity in the deep water (Rydberg \& Sundberg 1986). The halocline is usually located at about $15 \mathrm{~m}$, and the maximum depth of the bay is $20 \mathrm{~m}$. The investigations presented here were performed mainly in Laholm Bay, together with some in the Kattegat. They took place during October 1983, March 1984, September 1985 and April 1986. Samplings were performed aboard RV 'Argos' and RV 'Ancylus'. They will be treated as belonging to either of the following 2 groups. Group 1 included the central outer part of Laholm Bay and the stations Anholt E, Fladen, Gniben and $\mathrm{KX} 1$ in the Kattegat (Fig. 1). On 4 occasions, variations of the rate of ammonium regeneration with depth were also investigated. In March 1984 and September 1985 diel studies were performed in which samples were collected at $6 \mathrm{~h}$ intervals from $18: 00 \mathrm{~h}$ to 12:00 h the next day. Group 2 included a transect from the outlet of the river Nissan extending $8 \mathrm{~km}$ out into Laholm Bay. The stations were N1, N2, N3, N10 and 15 (Fig. 1)

Sampling. Water samples were taken with either a 301 Niskin bottle (for specific depths), or 51 Niskin bottles. In the latter case, water was collected from the upper part of the water column (0 to $6 \mathrm{~m}$ ), poured into a 601 polyethylene container and mixed manually. The water was then divided into subsamples for incubation experiments and water analysis.

Analytical methods. Ammonium was analysed by the phenol-hypochlorite method of Solorzano, modified according to Koroleff (1976). Nitrite and nitrate were analysed on a Technicon AutoAnalyzer I according to Armstrong et al. (1967). Samples for particulate organic carbon and nitrogen were collected on Whatman GF/F glass fiber filters (precombusted for $2 \mathrm{~h}$ at $450^{\circ} \mathrm{C}$ ), and 
later analysed on a Carlo Erba Elemental Analyser model 1106.

Determination of the rate of ammonium regeneration. Water was collected as described above, and poured into $2.6 \mathrm{l}$ polycarbonate bottles. No prescreening of the water was done. Incubations were started immediately. A total of $4 \mu \mathrm{mol}$ ammonium chloride (50 atom $\%{ }^{15} \mathrm{~N}$ ) was added per liter. The containers were incubated on deck under $50 \%$ ambient light intensity in running surface seawater. Duration of the incubation varied from 4 to $8 \mathrm{~h}$. Samples for analysis of ammonium content and for determination of atom $\%{ }^{15} \mathrm{~N}$ were taken both at the start and at the end of the incubation. After addition of extraction reagents (Selmer \& Sörensson 1986) the samples were stored in dark glass bottles until further analysis. Solid phase extraction (on octadecylsilane separation columns) of ammonium (derivatised as indophenol) was performed according to Selmer \& Sörensson (1986) with subsequent Dumas combustion of the sample. Analysis of atom $\%{ }^{15} \mathrm{~N}$ was done by emission spectrometry (Station NOI-5 ${ }^{15} \mathrm{~N}$ Analyzer). The rate of ammonium regeneration was calculated according to the Blackburn-Caperon model (Blackburn 1979, Caperon et al. 1979). No corrections for contamination in the measured atom $\%{ }^{15} \mathrm{~N}$ were done. In the Blackburn-Caperon model, however, rates of regeneration are calculated from changes in relative ${ }^{15} \mathrm{~N}$-enrichment and are thus not very sensitive to the absolute value used. The precision of the method (i.e. isotope dilution with an addition of $4 \mu \mathrm{mol}$ ammonium per liter and solid phase extraction) has been determined separately (Selmer unpubl.) and have shown to have a coefficient of variation of $0.5(n=9)$. This is based on 3 parallels of both initial and final atom $\%{ }^{15} \mathrm{~N}$ in the ammonium pool, and the ammonium regeneration rate is based on an average atom $\%{ }^{15} \mathrm{~N}$ of these parallels.

\section{RESULTS}

\section{Kattegat and central outer Laholm Bay}

Data for these stations are given in Table 1. In the central outer part of Laholm Bay and Kattegat, the ammonium regeneration rates ranged from 5 to 141

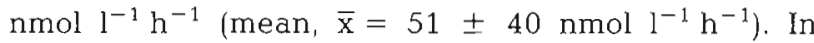
Laholm Bay, the mean rates in autumn were 2.5 times higher than those measured during spring. In autumn, they ranged from 21 to $91 \mathrm{nmol} l^{-1} \mathrm{~h}^{-1}(\overline{\mathrm{x}}=62 \pm 27$ nmol $1^{-1} \mathrm{~h}^{-1}$, and in spring from 12 to $38 \mathrm{nmol} \mathrm{l}^{-1} \mathrm{~h}^{-1}$

Table 1. Ammonium regeneration in the Kattegat (Anholt E, Fladen, Gniben and KX1) and the central outer part of Laholm Bay (L). All samples were collected around noon, except when otherwise indicated. 0-6 m indicates an integrated sample from the upper photic zone. The ratio $U: R$ is the ammonium uptake rate ( $E$. Sahlsten pers. comm.) divided by the ammonium regeneration rate

\begin{tabular}{|c|c|c|c|c|c|c|c|}
\hline Date & Station & $\begin{array}{l}\text { Depth } \\
(\mathrm{m})\end{array}$ & $\begin{array}{c}\mathrm{NH}_{4}^{+} \text {regeneration } \\
\left(\mathrm{nmol} \mathrm{l} \mathrm{l}^{-1} \mathrm{~h}^{-1}\right)\end{array}$ & $\mathrm{NH}_{4}^{+}$ & $\begin{array}{c}\mathrm{NO}_{3}^{+} \\
\left(\mu \mathrm{mol} 1^{-1}\right)\end{array}$ & Part. $N$ & $U: R$ \\
\hline \multicolumn{8}{|l|}{ Spring } \\
\hline \multirow[t]{2}{*}{7 Mar 1984} & L & $0-6$ & 18 & 0.00 & 4.83 & 3.0 & 0.51 \\
\hline & $I$ & 14 & 58 & 0.05 & 10.97 & 1.0 & 0.03 \\
\hline $8 \mathrm{Mar}$ & L & $0-6$ & 12 & 0.01 & 6.79 & 3.4 & 0.88 \\
\hline $12 \mathrm{Mar}$ & Fladen & $0-6$ & 108 & 0.00 & 0.06 & 6.4 & - \\
\hline $13 \mathrm{Mar}$ & Anholt E & $0-6$ & 141 & 0.01 & 0.09 & 6.1 & - \\
\hline $14 \mathrm{Mar}$ & L & $0-6$ & 35 & 0.00 & 1.62 & 4.2 & 0.31 \\
\hline $15 \mathrm{Mar}$ & $\mathrm{L}$ & $0-6$ & 33 & 0.00 & 1.50 & 5.1 & 0.24 \\
\hline $21 \mathrm{Mar}$ & $\mathrm{L}$ & $0-6$ & 38 & 0.00 & 0.23 & 2.7 & 0.65 \\
\hline \multirow[t]{2}{*}{27 Mar 1985} & $\mathrm{~L}$ & 6.5 & 116 & 0.73 & 0.13 & 4.5 & 0.55 \\
\hline & $\mathrm{L}$ & 11 & 106 & 0.47 & 0.17 & 6.2 & 0.42 \\
\hline 2 Apr 1986 & L & 1.5 & 16 & 0.30 & 1.50 & 1.8 & 0.15 \\
\hline \multicolumn{8}{|l|}{ Autumn } \\
\hline \multirow{2}{*}{$\begin{aligned} 16 \operatorname{Sep} & 1985 \\
& (07: 30 \mathrm{~h})\end{aligned}$} & $\mathrm{KX} 1$ & $0-6$ & 15 & 0.10 & 0.18 & 1.8 & 0.50 \\
\hline & Gniben & $0-6$ & 20 & 0.10 & 0.07 & 2.3 & 0.56 \\
\hline \multirow[t]{3}{*}{17 Sep } & $\mathrm{L}$ & $0-6$ & 21 & 0.09 & 0.02 & 3.4 & 0.23 \\
\hline & $\mathrm{L}$ & 13 & 11 & 0.32 & 0.27 & 2.4 & 2.14 \\
\hline & $\mathrm{L}$ & 23 & 5 & 1.64 & 0.44 & 1.1 & 3.07 \\
\hline \multirow{3}{*}{$\begin{array}{r}18 \operatorname{Sep}(00: 55 \mathrm{~h}) \\
(00: 55 \mathrm{~h})\end{array}$} & $\mathrm{L}$ & $0-6$ & 60 & 0.00 & 0.00 & 3.7 & 0.27 \\
\hline & $\mathrm{L}$ & 21 & 27 & 0.20 & 0.30 & 2.0 & 0.18 \\
\hline & L & $0-6$ & 57 & 0.02 & 0.20 & 3.5 & 0.28 \\
\hline \multirow[t]{2}{*}{19 Sep } & L & $0-6$ & 91 & 0.02 & 0.03 & 2.7 & 0.18 \\
\hline & $\mathrm{L}$ & $0-6$ & 83 & 0.00 & 0.03 & 4.6 & 0.19 \\
\hline 13 Oct 1983 & $\mathrm{~L}$ & $0-6$ & 57 & 0.41 & 0.38 & 3.8 & 0.10 \\
\hline
\end{tabular}


$\left(\overline{\mathrm{x}}=25 \pm 11 \mathrm{nmol} \mathrm{l}^{-1} \mathrm{~h}^{-1}\right)$. Regeneration rates increased with depth. The 2 depth profiles of ammonium regeneration performed during spring reflected the development of the spring bloom (Table 1), as the rates were more elevated with depth after the spring bloom (27 March) than at the onset of the spring bloom (7 March). An extremely high particulate nitrogen content (ca $6 \mu \mathrm{mol} \mathrm{l}^{-1}$ ) and very high ammonium regeneration rates were observed in the Kattegat during the spring bloom period (108 and $141 \mathrm{nmol} \mathrm{l}^{-1} \mathrm{~h}^{-1}$ for Fladen and Anholt E, respectively). During early autumn (September), the ammonium regeneration rates were similar in the Kattegat and Laholm Bay (ca 15 to $20 \mathrm{nmol} \mathrm{l}^{-1} \mathrm{~h}^{-1}$ ). Later (concomitant with dinoflagellate blooms), the rates had increased 5-fold. In autumn, the depth profiles of ammonium regeneration showed rates that decreased with depth.

Results from the 2 diel studies are shown in Fig. 2. In

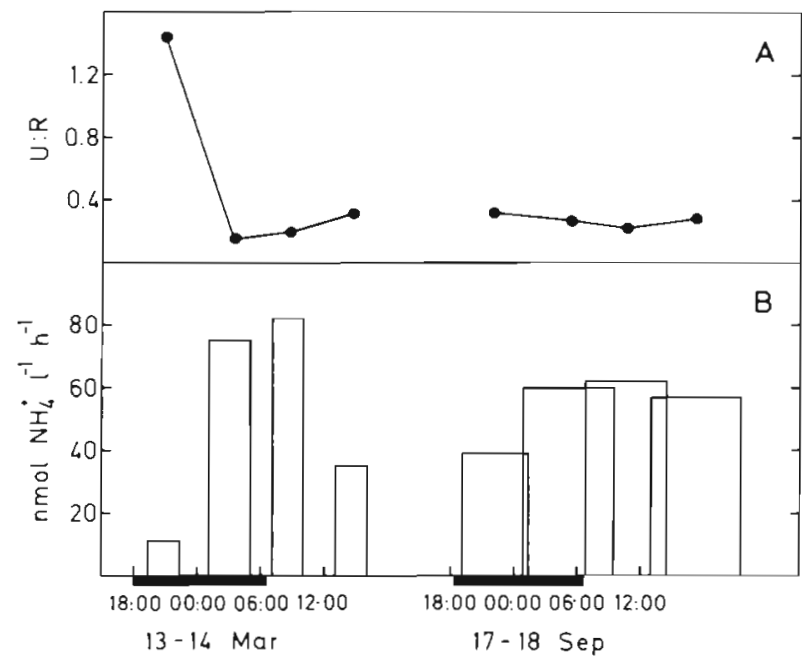

Fig. 2. Diel variations in ammonium dynamics during March 1984 and September 1985. (A) The ratio $U: R$ based on the rates of ammonium uptake (U) (Sahlsten et al. 1988) and ammonium regeneration (R). (B) Ammonium regeneration rate. Columns extend over the period for which the incubation lasted. Shaded bars on the $x$-axis indicate periods of darkness

the first study (March), the ammonium regeneration rate was 7 times higher during the night and morning $\overline{\mathrm{x}}=79 \mathrm{nmol} \mathrm{l}^{-1} \mathrm{~h}^{-1}$ ) than in the evening (11 nmol $\left.\mathrm{l}^{-1} \mathrm{~h}^{-1}\right)$, and 2.3 times higher than during the afternoon (35 $\mathrm{nmol} 1^{-1} \mathrm{~h}^{-1}$ ). In the second diel study (September), ammonium regeneration also exhibited diel variations although not as clearly expressed as during spring. The rate was ca $60 \mathrm{nmol} \mathrm{l}^{-1} \mathrm{~h}^{-1}$ during the night, morning and afternoon. This was 1.5 times higher than in the evening (39 nmol $\mathrm{l}^{-1} \mathrm{~h}^{-1}$ ). Applying a coefficient of variation of 0.5 (Selmer unpubl.) to these data implies that the diel variation observed in spring was real while the variation in autumn was within the error of the method. The diel variations resulted in a diel factor (average hourly regeneration rate over the $24 \mathrm{~h}$ period/ hourly regeneration rate from daytime measurements) of 1.45 for spring and 0.96 for autumn.

\section{Transect}

Ammonium regeneration rates observed in the transect ranged from 2 to $137 \mathrm{nmol} \mathrm{l}^{-1} \mathrm{~h}^{-1},(\overline{\mathrm{x}}=49 \pm 40$ nmol $\left.\mathrm{l}^{-1} \mathrm{~h}^{-1}\right)$. In autumn, the rates were 1.5 times higher than in spring. In spring, the rates varied between 24 and $49 \mathrm{nmoll}^{-1} \mathrm{~h}^{-1}\left(\overline{\mathrm{x}}=35 \pm 13 \mathrm{nmoll}^{-1} \mathrm{~h}^{-1}\right)$ and in autumn between 2 and $137 \mathrm{nmol} \mathrm{l}^{-1} \mathrm{~h}^{-1}(\overline{\mathrm{x}}=53$ $\pm 44 \mathrm{nmol} \mathrm{l}^{-1} \mathrm{~h}^{-1}$ ) (Table 2 ). No correlations between ammonium regeneration rates and distance from the river mouth were found.

In general, nutrient concentrations were highest at the river mouth, with nitrate being about $15 \mu \mathrm{mol} \mathrm{l}^{-1}$ at $\mathrm{N} 1, \mathrm{~N} 2$ and $\mathrm{N} 3$ and ammonium between 1.2 and 3.8 $\mu \mathrm{mol} \mathrm{l}^{-1}$. Elevated $\mathrm{C} / \mathrm{N}$ atomic ratios of up to 20 were observed at the river mouth. This indicates that much of the organic material transported with the river was refractory (e.g. humic compounds) and not available for biological degradation. Further out from the river, the $\mathrm{C} / \mathrm{N}$ ratio decreased to between 7.6 and 9.1 due to a mixing of the river water with bay water.

\section{DISCUSSION}

The ammonium regeneration rates presented here are mostly in the same order of magnitude as those reported in the literature (Table 3 ). The relationship between uptake $(U)$ and regeneration $(R)$ of ammonium can be expressed as the ratio $U: R$. Calculations of $U: R$ from this study exhibited a large variability with predominantly $U: R$ of $<1$ (Tables 1 and 2 ; uptake rates are cited from Pettersson et al. unpubl. and E. Sahlsten pers, comm.). In the literature, values of $U: R<1$ have prevailed, both from ecosystems with high and from those with low ambient ammonium concentrations (Table 3). In enclosure studies (CEPEX; Harrison 1978), the dominance of ammonium regeneration over uptake led to an accumulation of ammonium within the enclosure. In another enclosure experiment, however, no such effects on ammonium concentrations were observed even if $U: R<1$ (Sörensson et al. unpubl.)

It is evident from Table 3 that the relationships between uptake and regeneration rates as reported in the literature are very variable, and uptake is usually exceeded by regeneration. This phenomenon was discussed by Kokkinakis \& Wheeler (1987) who suggested that the ammonium regeneration rates were overestimated. This could, for example, be caused by handling of the water sample and bottle confinement /Glibert 
Table 2. Transect stations in Laholm Bay. All samples were collected from the upper part of the photic zone (integrated sample $0-6 \mathrm{~m}$ ). The ratio $U: R$ is the ammonium uptake rate (Pettersson et al. unpubl.) divided by the ammonium regeneration rate

\begin{tabular}{|c|c|c|c|c|c|c|c|c|}
\hline Date & Station & $\begin{array}{c}\text { Distance from } \\
\text { river mouth } \\
(\mathrm{km})\end{array}$ & $\begin{array}{c}\mathrm{NH}_{4}^{-} \\
\text {regeneration } \\
\left(\text { nmol l-1 } \mathrm{h}^{-1}\right)\end{array}$ & $\begin{array}{c}\mathrm{NH}_{4}^{+} \\
\left(\mu \mathrm{mol} \mathrm{l} l^{-1}\right)\end{array}$ & $\begin{array}{c}\mathrm{NO}_{3}^{+} \\
\left(\mu \mathrm{mol} 1^{-1}\right)\end{array}$ & $\begin{array}{c}\text { Part. N } \\
\left(\mu \mathrm{mol} \mathbf{1}^{-1}\right)\end{array}$ & $\begin{array}{c}\mathrm{C} / \mathrm{N} \text { atomic } \\
\text { ratio }\end{array}$ & $U: R$ \\
\hline $\begin{array}{l}\text { Spring } \\
8 \text { Mar } 1984\end{array}$ & $\begin{array}{l}\text { N } 3 \\
\text { N } 10\end{array}$ & $\begin{array}{l}3.4 \\
5.7\end{array}$ & $\begin{array}{l}49 \\
31\end{array}$ & $\begin{array}{l}1.74 \\
0.54\end{array}$ & $\begin{array}{l}7.7 \\
6.9\end{array}$ & $\begin{array}{l}7.4 \\
3.7\end{array}$ & $\begin{array}{r}12.3 \\
7.6\end{array}$ & $\begin{array}{l}1.22 \\
0.70\end{array}$ \\
\hline 2 Apr 1986 & N3 & 3.4 & 24 & 3.75 & 8.5 & 1.9 & 16 & 0.42 \\
\hline $\begin{array}{l}\text { Autumn } \\
19 \text { Sep } 1985\end{array}$ & $\begin{array}{l}\text { N1 } \\
\text { N2 } \\
\text { N3 } \\
\text { N10 } \\
15\end{array}$ & $\begin{array}{l}0.0 \\
1.7 \\
3.4 \\
5.7 \\
8.0\end{array}$ & $\begin{array}{r}96 \\
9 \\
17 \\
70 \\
69\end{array}$ & $\begin{array}{l}1.50 \\
2.03 \\
1.15 \\
0.10 \\
0.00\end{array}$ & $\begin{array}{r}15.1 \\
15.6 \\
15.5 \\
0.5 \\
0.1\end{array}$ & $\begin{array}{l}7.3 \\
7.6 \\
5.3 \\
4.2 \\
4.8\end{array}$ & $\begin{array}{r}20.1 \\
18.5 \\
10.8 \\
7.8 \\
8.1\end{array}$ & $\begin{array}{l}0.29 \\
2.94 \\
1.60 \\
0.17 \\
0.25\end{array}$ \\
\hline 11 Oct 1983 & $\begin{array}{l}\text { N3 } \\
\text { N } 10 \\
15\end{array}$ & $\begin{array}{l}3.4 \\
5.7 \\
8.0\end{array}$ & $\begin{array}{r}137 \\
18 \\
70\end{array}$ & $\begin{array}{l}1.53 \\
1.48 \\
0.84\end{array}$ & $\begin{array}{l}3.4 \\
1.7 \\
1.1\end{array}$ & $\begin{array}{l}4.5 \\
3.5 \\
3.8\end{array}$ & $\begin{array}{l}8.2 \\
8.1 \\
8.3\end{array}$ & $\begin{array}{l}0.07 \\
0.65 \\
0.17\end{array}$ \\
\hline $12 \mathrm{Oct}$ & $\begin{array}{l}\text { N3 } \\
\text { N10 }\end{array}$ & $\begin{array}{l}3.4 \\
5.7\end{array}$ & $\begin{array}{l}39 \\
99\end{array}$ & $\begin{array}{l}1.55 \\
0.76\end{array}$ & $\begin{array}{l}2.0 \\
0.9\end{array}$ & $\begin{array}{l}4.2 \\
7.2\end{array}$ & $\begin{array}{l}8.5 \\
8.6\end{array}$ & $\begin{array}{l}- \\
-\end{array}$ \\
\hline 13 Oct & $\begin{array}{l}\text { N } 3 \\
15\end{array}$ & $\begin{array}{l}3.4 \\
8.0\end{array}$ & $\begin{array}{r}10 \\
2\end{array}$ & $\begin{array}{l}2.75 \\
0.43\end{array}$ & $\begin{array}{l}5.2 \\
1.0\end{array}$ & $\begin{array}{l}4.4 \\
4.5\end{array}$ & $\begin{array}{l}9.1 \\
8.7\end{array}$ & $\begin{array}{l}0.74 \\
2.70\end{array}$ \\
\hline
\end{tabular}

Table 3. Rates of ammonium regeneration $(R)$ and uptake $(U)$, the ratio between these rates (U:R), ambient ammonium concentrations, and ammonium enrichment of the incubation, selected from the literature. Mean values are calculated from the rates of ammonium regeneration and uptake reported in the cited literature

\begin{tabular}{|c|c|c|c|c|c|c|c|}
\hline Geographical area & & $\begin{array}{l}\mathrm{NH}_{4}^{+}- \\
\text {reg. } \\
\text { (nmol l }\end{array}$ & $\begin{array}{c}\mathrm{NH}_{4}^{+}- \\
\text {uptake } \\
\left.1^{-1} \mathrm{~h}^{-1}\right)\end{array}$ & $U: R$ & $\begin{array}{r}\mathrm{NH}_{4}^{+} \\
(\mu \mathrm{mol})\end{array}$ & $\begin{array}{l}\mathrm{NH}_{4}^{+}- \\
\text {richment } \\
-1)\end{array}$ & Source \\
\hline CEPEX, Canada & $\begin{array}{l}\text { mean } \\
\text { range }\end{array}$ & $\begin{array}{r}40 \\
24-62\end{array}$ & $\begin{array}{r}25 \\
13-47\end{array}$ & $\begin{array}{r}0.65 \\
0.3-1.35\end{array}$ & $\begin{array}{r}2.51 \\
0.21-9.22\end{array}$ & 0.5 & Harrison 1978 \\
\hline $\begin{array}{l}\text { Southern California } \\
\text { Bight, USA. }\end{array}$ & $\begin{array}{l}\text { mean } \\
\text { range }\end{array}$ & & & $\begin{array}{r}0.77 \\
0.2-3.19\end{array}$ & $\begin{array}{r}0.74 \\
0.18-1.88\end{array}$ & 0.5 & Harrison 1978 \\
\hline Kaneohe, Bay, Hawaii & $\begin{array}{l}\text { mean } \\
\text { range }\end{array}$ & $\begin{array}{r}64 \\
0-210\end{array}$ & & & & 10 & Caperon et al. 1979 \\
\hline Oslo Fjord, Norway & $\begin{array}{l}\text { mean } \\
\text { range }\end{array}$ & $\begin{array}{r}28 \\
0-61\end{array}$ & $\begin{array}{r}194 \\
143-217\end{array}$ & $\begin{array}{r}7.14 \\
3.6-16.7\end{array}$ & & 4 & Paasche \& Kristiansen 1982 \\
\hline $\begin{array}{l}\text { Bedford Basin, Canada, } \\
\text { spring }\end{array}$ & $\begin{array}{l}\text { mean } \\
\mathrm{SD}\end{array}$ & $\begin{array}{l}41 \\
80\end{array}$ & $\begin{array}{r}115 \\
71\end{array}$ & 2.80 & $\begin{array}{l}1.43 \\
1.17\end{array}$ & 1 & LaRoche 1983 \\
\hline Bedford Basin, summer & $\begin{array}{l}\text { mean } \\
\mathrm{SD}\end{array}$ & $\begin{array}{r}66 \\
120\end{array}$ & $\begin{array}{l}182 \\
123\end{array}$ & 2.80 & $\begin{array}{l}1.13 \\
0.66\end{array}$ & 1 & LaRoche 1983 \\
\hline Gulf Stream & & 37 & 28 & 0.76 & 0.13 & 1 & Wheeler \& Kirchman 1986 \\
\hline Sapelo Island, GA, USA & $\begin{array}{l}\text { mean } \\
\text { range }\end{array}$ & $\begin{array}{r}136 \\
0-262\end{array}$ & $\begin{array}{r}69 \\
40-109\end{array}$ & $\begin{array}{r}0.40 \\
0.22-0.97\end{array}$ & $\begin{array}{r}2.61 \\
2.33-2.93\end{array}$ & 1 & Wheeler \& Kirchman 1986 \\
\hline Northwestern USA, & mean & & & 0.09 & & 0.1 & Kokkinakis \& Wheeler 1987 \\
\hline $\begin{array}{l}\text { Davies Reef, GBR, } \\
\text { Australia }\end{array}$ & range & $1-11$ & & & $0.07-0.37$ & 0.1 & Hopkinson et al. 1987 \\
\hline Baltic Sea & $\begin{array}{l}\text { mean } \\
\text { range }\end{array}$ & $\begin{array}{r}46 \\
28-50\end{array}$ & $\begin{array}{r}27 \\
19-51\end{array}$ & $\begin{array}{r}0.59 \\
0.36-1.3\end{array}$ & $\begin{array}{r}0.28 \\
0.14-0.66\end{array}$ & 4 & Sörensson et al. unpubl. \\
\hline Laholm Bay, central part & $\begin{array}{l}\text { mean } \\
\text { range }\end{array}$ & $\begin{array}{r}44 \\
12-91\end{array}$ & $\begin{array}{r}13 \\
2-24\end{array}$ & $\begin{array}{r}0.32 \\
0.1-0.88\end{array}$ & $\begin{array}{r}0.08 \\
0-0.41\end{array}$ & 4 & $\begin{array}{l}\text { Present study; uptake rates } \\
\text { from E. Sahlsten pers. comm. }\end{array}$ \\
\hline Laholm Bay, transect & $\begin{array}{l}\text { mean } \\
\text { range }\end{array}$ & $\begin{array}{r}49 \\
2-137\end{array}$ & $\begin{array}{r}19 \\
6-60\end{array}$ & $\begin{array}{r}0.41 \\
0.07-2.94\end{array}$ & $\begin{array}{r}1.37 \\
0-3.75\end{array}$ & 4 & $\begin{array}{l}\text { Present study; uptake rates } \\
\text { from Pettersson et al. unpubl. }\end{array}$ \\
\hline
\end{tabular}


1982). On the other hand, the observed discrepancy does not need to be a methodological artifact. It may either be real in those waters investigated, or the presumed balance between uptake and regeneration rates may not apply to the time scales involved in these experiments

The Blackburn-Caperon model presupposes that the measured regeneration rates are independent of the ${ }^{15} \mathrm{~N}$-ammonium enrichment. However, Axler et al. (1981) suggested that the ammonium enrichment might have an effect on the regeneration rates, but did not subsequently investigate this. In the investigations cited in Table 3, there were large differences in the ammonium additions. Experiments have shown the ammonium regeneration rate to be dependent on the ammonium enrichment up to about $100 \%$ (percentage enrichment relative to the in situ concentration), after which the rate stabilises at a constant level (Selmer unpubl.). This may be due to an enrichment effect on the total plankton community. An increased ammonium uptake by both bacteria and phytoplankton could lead to an increased release of bacterial nitrogen through grazing, and increased exudate release by phytoplankton. As the regeneration rates presented here are based on an ammonium addition of $4 \mu \mathrm{mol} \mathrm{l}^{-1}$, it is reasonable to believe that the enrichment effect was constant in all the incubations. The observed rates should therefore be considered as potential rates. This is in agreement with the conclusion reached by Cochlan (1986) that 'regeneration rates determined by isotope-dilution technique, are not necessarily indicative of the actual rates occurring in the environment but signify the potential contribution of local recycling to phytoplankton nitrogen ration'. This is also in accordance with the conclusion made by Glibert (1982).

There could also be a biological explanation to the discrepancy if other processes such as nitrification were occurring simultaneously with ammonium regeneration, and utilising the ammonium produced. However, nitrification in the upper part of the photic zone is thought to be light inhibited (Olson 1981) and thus negligible. During 2 studies in the central outer part of Laholm Bay in summer, nitrification activity was either undetectable or minor $\left(<10 \mathrm{nmol} \mathrm{l}^{-1} \mathrm{~h}^{-1}\right)$ in the upper photic layer (measured as ${ }^{15} \mathrm{~N}$-ammonium oxidation; $\mathrm{V}$ Enoksson pers. comm.). Consequently, nitrification cannot explain the differences observed here.

The excess of ammonium regeneration over ammonium uptake may be reduced somewhat if the ammonium uptake rates are corrected for substrate isotope dilution. When using the average atom $\%{ }^{15} \mathrm{~N}$ enrichment of the ammonium pool (Glibert et al. 1982), uptake rates have been found to be underestimated by a factor of between 1.0 and 4.4 (Harrison \& Harris 1986). For the uptake data cited here, no such correc- tions were performed, since the rate determinations of uptake and regeneration were done in separate incubation bottles, and with different amounts of substrate addition. From the central outer part of Laholm Bay, however, Sahlsten et al. (1988) corrected ammonium uptake data using the method of Kanda et al. (1987). Assuming regeneration rates equal to uptake rates, they found a maximum correction factor of 1.35, and, assuming regeneration to be twice as high as uptake (i.e. $U: R=0.5$ ), obtained a maximum factor of 1.89 . However, this would not suffice to make uptake and regeneration rates equal. In conclusion, the ratios of $U: R$ observed here should be treated with caution, due to the uncertainties inherent in both uptake and regeneration rates.

If the ammonium regeneration rates are potential rates, it should be more useful to compare them with the fraction of regenerated production, instead of the measured nutrient uptake rates. The ratio (f) of new production/total production (total production $=$ the sum of ammonium, nitrate and urea uptake) describes the probability of a nitrogen atom giving rise to new production and thus $1-f$ is the probability of giving rise to regenerated production (Eppley \& Peterson 1979). The recycling factor $r$, which equals $(l-f) / f$, describes how many times a nutrient is recycled before it is exported out of the system (Eppley \& Peterson 1979). Consequently, the recycling factor and the ammonium regeneration rate should be closely coupled.

This concept of new and regenerated production, however, presumes that there is no allochthonous supply of reduced nitrogen (Eppley \& Peterson 1979) and should therefore not be applicable to Laholm Bay. Although nitrate is the main nutrient transported to Laholm Bay by rivers, elevated ammonium concentrations are always observed at the river mouth (Table 2). The nutrient input to Laholm Bay is mainly

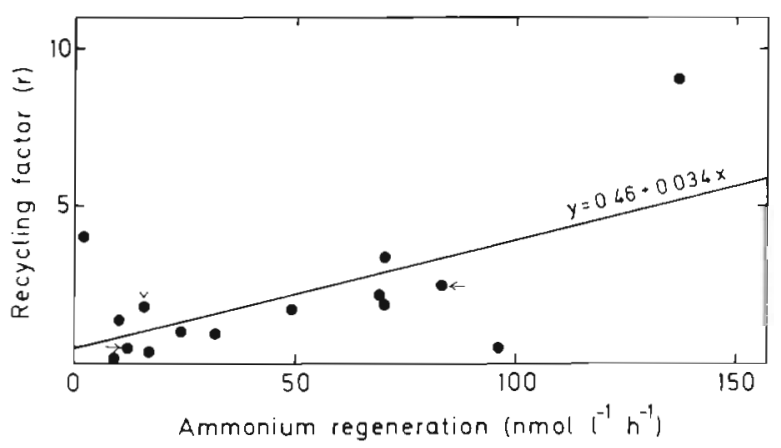

Fig. 3. Correlation between the recycling factor $r$ (based on uptake rates by Pettersson et al. unpubl.) and the ammonium regeneration rate for the transect stations in Laholm Bay. Arrows indicate observations from the central outer part of Laholm Bay made simultaneously with observations in the transect. The line of regression is drawn, for which the equation is given. Coefficient of correlation $=0.61$ 
assimilated close to the river outlets (Graneli et al. 1986). The harbour basin of the river Nissan has an area of $2 \mathrm{~km}^{2}$ and thus a daily supply of about 0.3 tonne ammonium from the river (total input of inorganic nitrogen $=1$ to 1.5 tonne $d^{-1}$, of which $20 \%$ is ammonium; Rydberg 1986) results in an ammonium input equal to $450 \mathrm{nmol} \mathrm{m}-2 \mathrm{~h}^{-1}$. In these inner parts of Laholm Bay where there is no halocline preventing an upward transport of nutrients, benthic nutrient regeneration will also supply the water with allochthonous ammonium (giving rise to new production). Sandy sediment cores taken in September in Laholm Bay were found to release $5 \mu \mathrm{mol} \mathrm{NH} \mathrm{N}^{+} \mathrm{m}^{-2} \mathrm{~h}^{-1}$, and $80 \mu \mathrm{mol} \mathrm{NH}+$ $\mathrm{m}^{-2} \mathrm{~h}^{-1}$ when dead algal material was added (Enoksson unpubl.). Assuming that this benthic ammonium regeneration occurred at a depth of $10 \mathrm{~m}$ (corresponding to Stn N10) an addition of 0.5 and $8 \mathrm{nmol} \mathrm{NH}_{4}^{+}$ $\mathrm{l}^{-1} \mathrm{~h}^{-1}$ would result for these 2 cases, respectively. This rate is low compared to both the ammonium input from the rivers, and to most of the ammonium regeneration rates observed in this study. The major part of benthic nutrient regeneration in the shallow parts of Laholm Bay, however, is supplied by suspension-feeding bivalves. In autumn, these have been shown to be responsible for $97 \%$ of the decomposition of seston (at depths down to $10 \mathrm{~m}$ ), while the remaining $3 \%$ was due to macrozooplankton (R. Rosenberg pers. comm.).

In spite of the limitations discussed above, there is a positive correlation $(p<0.01)$ between the rate of ammonium regeneration and the recycling factor $r$ for the transect stations (Fig. 3). This comparison inciudes the central outer part of Laholm Bay (sampled simultaneously with the transect) where the concept of Eppley \& Peterson (1979) is applicable (Sahlsten et al. 1988). It is impossible to speculate on the degree of overestimation of $r$ at the inner stations (due to the allochthonous ammonium input). However, assuming that $r$ is a relative measure of the regenerated production, ammonium regeneration is proportional to the regenerated production even if there is an external input of ammonium to the photic zone.

Ammonium recycling in the inner parts of Laholm Bay may also be discussed in terms of turnover time. Dividing mean concentration by mean regeneration according to Table 2 gives an average of $79 \mathrm{~h}$. Assuming that the rates are overestimated by a factor of 4 (based on author's unpubl. data) the turnover time is thus about $13 \mathrm{~d}$, which is certainly a very high value. High concentrations of ammonium, on the other hand, are mainly due to the river and waste water supply, and are not regulated by uptake and regeneration. From that point of view, the turnover time is overestimated. Hydrographic measurements (L. Rydberg \& J. Sundberg pers. comm.) have shown that mixing between river water and 'bay water' increased the mean salinity by a factor of 6 between Stns N1/N2 and N10/15, indicating a corresponding decrease in ammonium concentration and a considerably lowered turnover time ( 2 to $3 \mathrm{~d}$ )

The rate of ammonium regeneration was clearly affected by the development of the spring bloom (Table 1), since it increased about 9 -fold from the onset to the peak of the spring bloom. At the peak of the spring bloom, very high concentrations of particulate nitrogen were observed at both Fladen and Anholt $E$ (Table 1), concomitant with high chlorophyll a concentrations (10.3 and $5.5 \mathrm{mg} \mathrm{m}^{-3}$ for Fladen and Anholt $\mathrm{E}_{\text {, }}$ respectively; L. Edler pers. comm.). When the rate of ammonium regeneration was highest $\left(141 \mathrm{nmol} \mathrm{l}^{-1} \mathrm{~h}^{-1}\right.$ at Anholt E), the lower chlorophyll a concentration indicated that the particulate nitrogen was more detrital and thus more easily degradable. This resulted in high substrate availability for the heterotrophic organisms responsible for ammonium regeneration, and thus gave rise to the elevated rates of ammonium regeneration observed. Combined with the low or depleted ambient ammonium concentrations observed, these regeneration rates gave the lowest turnover times observed in the present study $(0.07 \mathrm{~h}$ for Anholt E) Afterwards, the rates decreased to a level about 3 times as large as those observed during the onset of the spring bloom. In April, rates of ammonium regeneration had declined further, to a level equal to those observed during the onset of the spring bloom, probably reflecting a decreasing activity in the heterotrophic population.

The diel variations were very pronounced after the peak of the spring bloom (Fig. 2) with rates of ammonium regeneration far in excess of those of uptake (Sahlsten et al. 1988) during night-time, while in the evening the pattern was opposite. The higher rates of ammonium regeneration observed during night are consistent with data presented by Glibert (1982) from the Sargossa Sea, where regeneration rates observed at first light $(05: 30 \mathrm{~h})$ showed values up to 6 times higher than those reported at midday. Contrary to this study, Caperon et al. (1979) found the rates of regeneration to be equal to the rates of uptake on a $24 \mathrm{~h}$ scale, even if regeneration exceeded uptake during night. In the present study, the average ratio of $U: R$ was 0.53 in spring and 0.27 in autumn (Fig. 2). The diel variations observed during spring could be due to vertical zooplankton migration (Glibert 1982). However, this is not supported by the low biomass of macrozooplankton observed during spring (Båmstedt 1986). Today, however, the dominating concept of microbial food webs is that the bacterivorous protozoa (mostly heterotrophic microflagellates $<20 \mu \mathrm{m}$ ) and microzooplankton $(<200 \quad \mu \mathrm{m})$ are the most important regenerators of ammonium (the microbial loop; Azam 
et al. 1983). Heterotrophic microflagellates are present in pelagic waters throughout the year. Diel studies of their predation on bacteria have shown highest consumption rates mainly during daytime, but maximum predation has also been observed during the night (Wikner et al. unpubl.). This latter diel pattern is in accordance with the results observed in the present study

There was a seasonal pattern in the depth profiles: rates were increasing with depth in spring and vice versa in autumn. The high regeneration rates observed down to $11 \mathrm{~m}$ after the spring bloom are most probably a result of a decaying and sedimenting phytoplankton bloom, as seen in the high particulate nitrogen concentrations. High recycling factors ( $r$ was in the range 2 to 4; E. Sahlsten pers. comm.) were also an indication of the importance of ammonium regeneration in this case. In autumn there was a decrease in regeneration rates with depth. This is in agreement with the decreasing amounts of particulate nitrogen observed with depth.

In autumn, the measured rates of ammonium regeneration in the central part of Laholm Bay were 2.5 times higher than during spring (Table 1). This seasonal variation is consistent with the variations in zooplankton excretion reported from Koster Fjord (west coast of Sweden) by Båmstedt (1985), where the total nitrogenous excretion by macrozooplankton was highest during autumn due to elevated standing stocks. A higher biomass of macrozooplankton during autumn as compared to spring, was also reported from Laholm Bay by Båmstedt (1986) for the period 1982 to 1985 . This seasonal variation may be due to differences in water temperature. As metabolic activities would be expected to increase with increasing temperature, this would result in higher rates of ammonium regeneration. During the periods investigated, the water temperature was about $1{ }^{\circ} \mathrm{C}$ in spring and 10 to $14^{\circ} \mathrm{C}$ in autumn. The difference between the seasons in the fractions of ammonium uptake, however, was not so distinct, as the average percentage of ammonium uptake in spring was $43 \%$ and in autumn $56 \%$ of the total nitrogen uptake (Sahlsten et al. 1988). Applying the diel factor of 1.45 and 0.96 for spring and autumn, respectively, resulted in a decreased seasonal variation, where the rate in autumn was 1.5 times higher than in spring. However, this is based on only 2 measurements of diel variations which may not be applicable to the whole spring or autumn period, respectively.

\section{CONCLUSIONS}

The following can be summarised from this study:

(1) The ammonium regeneration rate was positively correlated with the recycling factor $r$ in an area with allochthonous ammonium input, even if the ammonium regeneration did not contribute to all of the regenerated production.

(2) Diel variations in the ammonium regeneration rate were observed during spring while in autumn the variations were within the error of the method.

(3) Seasonal variations were observed as the ammonium regeneration rates were higher in autumn than in spring. In spring, the rates increased with depth, while in autumn they decreased.

Acknowledgements. This work would not have been possible without the collaboration of Viveka Enoksson, Karin Pettersson, Elisabeth Sahlsten and Fred Sörensson in our Department, who also gave access to unpublished data on nutrients, particulate material, and rates of nitrogen uptake and nitrification. They also gave helpful comments on the manuscript. I am very grateful to Lena Rüdén and Anna-Kerstin Thell for skillful technical assistance, to Ulf Rönner for valuable discussions on the manuscript, to Lars Rydberg for helpful comments on the hydrographical aspects, to Nancy llenius for drawing the figures, to Maureen Jehler and Anita Renås for the typing of the manuscript, and to 3 anonymous referees for their valuable comments. I also thank the crews of RV 'Ancylus' and RV 'Argos' who made these investigations possible. This work was supported by grants from the Swedish Environment Protection Board.

\section{LITERATURE CITED}

Azam, F., Fenchel, T., Field, J. G., Gray, J. S., Meyer-Reil, L.-A., Thingstad, F. (1983). The ecological role of water-column microbes in the sea. Mar. Ecol. Prog. Ser. 10: 257-263

Armstrong, F. A. J., Stern, C. R., Strickland, J. D. H. (1967). The measurements of upwelling and subsequent biological processes by means of the Techmicon AutoAnalyser and associated equipment. Deep Sea Res, 14: 381-389

Axler, R. P., Redfield, G. W. Goldman, C. R. (1981). The importance of regenerated nitrogen to phytoplankton productivity in a subalpine lake. Ecology 62: 345-354

Blackburn, T H. (1979). Method for measuring rate of $\mathrm{NH}_{4}^{+}$ turnover in anoxic marine sediments, using a ${ }^{15} \mathrm{~N}_{-} \mathrm{NH}_{4}^{+}$ dilution technique. Appl. environ. Microbiol. 37. 760-765

Båmstedt, U. (1985). Seasonal excretion rates of macrozooplankton from the Swedish west coast. Limnol. Oceanogr. 30: $607-617$

Båmstedt, U. (1986). Zooplanktons roll. (The role of zooplankton). In: Rosenberg, R. (ed.) Eutrofieringsläget i Kattegatt. Report to Swedish Environment Protection Board 3272: 113-117 (Swedish)

Caperon, J., Schell, D., Hirota, J., Laws, E. (1979). Ammonium excretion rates in Kaneohe Bay. Hawaii, measured by a ${ }^{15} \mathrm{~N}$ isotope dilution technique. Mar. Biol. 54: 33-40

Cochlan, W. P. (1986). Seasonal study of uptake and regeneration of nitrogen on the Scotian Shelf. Cont. Shelf Res. 5: $555-557$

Dugdale, R. C., Goering, J J. (1967). Uptake of new and regenerated forms of nitrogen. in primary productivity. Limnol. Oceanogr. 12: 196-206

Edler, L. (1986). Växtplanktonproduktion i Laholmsbukten. (Phytoplankton production in Laholm Bay). In: Rosenberg. R. (ed.) Eutrofieringsläget i Kattegatt. Report to Swedish Environment Protection Board 3272: 66-71. (Swedish) 
Eppley, R. W., Peterson, B. J. (1979). Particulate organic matter flux and planktonic new production in the deep sea. Nature, Lond. 282: 677-680

Glibert, P. M. (1982). Regional studies of daily, seasonal and size fraction variability in ammonium remineralization. Mar Biol. 70: 209-222

Glibert, P. M., Lipschultz, F., McCarthy, J. J., Altabet, M. A (1982). Isotope dilution models of uptake and remineralization of ammonium by marine plankton. Limnol. Oceanogr. 27: 639-650

Goldman, J. C., Glibert, P. M. (1983). Kinetics of inorganic nitrogen uptake by phytoplankton. In: Carpenter, E. J., Capone, D. G. (eds.) Nitrogen in the marine environment. Academic Press, New York, p. 233-274

Graneli, E., Graneli, W., Rydberg, L. (1986). Nutrient limitation at the ecosystem and phytoplankton community level in the Laholm Bay, South-East Kattegatt. Ophelia 26 181-194

Harrison, W. G. (1978). Experimental measurements of nitrogen remineralization in coastal waters. Limnol. Oceanogr 23: $684-694$

Harrison, W G., Harris, L. R. (1986). Isotope-dilution and its effect on measurements of nitrogen and phosphorus uptake by oceanic microplankton. Mar. Ecol. Prog. Ser. 27 253-261

Hopkinson, Jr, C. S., Sherr, B. F., Ducklow, H. W. (1987) Microbial regeneration of ammonium in the water column of Davies Reef, Australia. Mar. Ecol. Prog. Ser. 41. 147-153

Kanda, J., Laws, E. A., Saino, T., Hattori, A. (1987). An evaluation of isotope dilution effect from conventional data sets of ${ }^{15} \mathrm{~N}$ uptake experiments. J. Plankton Res. 9: 79-90

Kokkinakis, S. A., Wheeler, P. A. (1987). Nitrogen uptake and phytoplankton growth in coastal upwelling regions. Limnol. Oceanogr. 32: 1112-1123

Koroleff, F. (1976). Determination of nutrients. In: Grasshoff, K. (ed.) Methods of seawater analysis. Verlag Chemie, New York, p. 117-182

Lakoche, J. (1983). Ammonium regeneration: its contribution to phytoplankton requirements in a eutrophic environment. Mar Biol. 75: 231-240

Laws, E. A. (1983). Man's impact on the marine nitrogen cycle.
In: Carpenter, E. J., Capone, D. C. (eds.) Nitrogen in the marine environment. Academic Press. New York, p. $459-486$

McCarthy, J. J. (1980). Nitrogen. In: Morris, I. (ed.) The physiological ecology of phytoplankton. University of California Press, Berkeley, p. 191-233

Olson, R. J. (1981). Differential photoinhibition of marine nitrifying bacteria: a possible mechanism for the formation of primary nitrite maximum. J. mar Res. 39: 227-238

Paasche, E., Kristiansen, S. (1982). Ammonium regeneration by microzooplankton in the Oslo Fjord. Mar Biol. 69 $55-63$

Rosenberg, R. (1985). Eutrophication - the future marine coastal nuisance? Mar Pollut. Bull. 16: 227-231

Rydberg, L. (1986). Observations on nutrient fluxes through the coastal zone. Rapp. P.-v. Réun. Cons. int. Explor. Mer 186: $49-59$

Rydberg, L., Sundberg, J. (1986). Seasonal nutrient supply to coastal waters. In: Nihoul, J. J. (ed.) Marine interfaces hydrodynamics. Elsevier Oceanography Series, 42 Elsevier, Amsterdam, p. 467-488

Ryther, J. H., Dunstan, W. M. (1971). Nitrogen, phosphorus and eutrophication in the coastal marine environment. Science 171: 1008-1013

Sahlsten, E., Sörensson, F., Pettersson, K. (1988). Planktonic nitrogen uptake in the south-east Kattegatt. J. exp. mar. Biol. Ecol. (in press)

Selmer, J.-S., Sörensson, F. (1986). New procedure for the extraction of ammonium from natural waters for ${ }^{15} \mathrm{~N}$ isotopic ratio determination. Appl. environ. Microbiol. 52 $577-579$

Smith, S. V., Kimmerer, W. J., Walsh, T W. (1986). Vertical flux and biogeochemical turnover regulate nutrient limitation of net organic production in the North Pacific Gyre. Limnol. Oceanogr. 31 161-167

Wassmann, P. (1986). Benthic nutrient regeneration as related to primary productivity in the West-Norwegian coastal zone. Ophelia 26: 443-456

Wheeler, P. A., Kirchman, D. L. (1986). Utilization of inorganic and organic nitrogen by bacteria in marine systems. Limnol. Oceanogr. 31: 998-1009 